\title{
UM AUTOR LÍTERO-HISTÓRICO EM PORTUGAL: A PROSA MODERNA DE ALEXANDRE HERCULANO
}

\section{UN AUTEUR LITERARY ET HISTORIQUE EN PORTUGAL: LA PROSE MODERNE D'ALEXANDRE HERCULANO}

\section{Hugo Lenes Menezes ${ }^{1}$}

Resumo: Atualmente, o cartesianismo está defasado. Vivemos a interdisciplinaridade. A unidade epistemológica é um imperativo, conforme ilustram as conexões entre a arte verbal e a ciência histórica, cuja estrutura em comum é o código narrativo. Como gêneros de fronteira, as narrativas ficcional e historiográfica se interpenetram. A ficção histórica, marco da prosa moderna em língua portuguesa, ao reconstituir ambientes e cotidianos, prefigura a história das mentalidades. Na lusofonia, o referido gênero literário, tipicamente romântico, inicia-se com Alexandre Herculano em Lendas e narrativas (1851). Assim, no presente artigo, objetivamos enfocar a prosa moderna de Herculano enquanto autor lítero-histórico.

Palavras-chave: Arte literária; ciência histórica; romantismo português; prosa moderna; Alexandre Herculano.

Résumé: Actuellement, le cartésianisme est dépassé. Nous vivons l'interdisciplinarité. L'unité épistémologique est nécessaire, comme le montrent les liens entre l'art verbal et la science historique, dont la structure commune est le code narratif. Comme genres de frontière, les récits fictifs et historiographiques s'interpénètrent. La fiction historique, qui est un point de repère de la prose moderne en portugais, en reconstituant les environnements et la vie quotidienne, prefigure l'histoire des mentalités. Dans la lusophonie, le genre littéraire susmentionné, typiquement romantique, commence avec Alexandre Herculano dans Légendes et récits (1851). Ainsi, dans cet article, nous avons cherché à aborder la prose moderne de Herculano entant qu'auteur littéraire et historique.

Mots-clés: Art littéraire; la science historique; romantisme portugais; prose moderne; Alexandre Herculano.

La fantasia ofrece más possibilidades que la realidad. Yo trato de colocar los acontecimientos setenta, noventa años atrás. Esto me da más libertad. [...] Y al fin de cuentas todo es mito, sin excluir nuestra vida pasada.

(Jorge Luis Borges)

As digressões são incontestavelmente a luz do sol, são a vida, a alma da leitura; retireias desse livro, por exemplo - e será melhor se tirardes o livro juntamente com ela.

(Laurence Sterne)

\footnotetext{
${ }^{1}$ Doutor em Teoria e História Literária pela Universidade Estadual de Campinas (UNICAMP), com Pós-Doutorado em Estudos Comparados de Literaturas de Língua Portuguesa pela Universidade de São Paulo (USP) e Aperfeiçoamento pelo Centre d'Approches Vivantes des Langues et des Médias (CAVILAM) de Vichy - França. Professor Titular do Departamento de Ciências Humanas e Letras do Instituto Federal de Educação, Ciência e Tecnologia do Piauí (IFPI). E-mail: hugomenezes@ifpi,edu.br
} 


\section{Considerações iniciais ${ }^{2}$}

Os últimos decênios mantêm-se como um período de crise. Vários são os desafios com que nos defrontamos, porquanto a visão mecanicista de mundo, de Descartes a Newton, bem como o sistema axiológico desse modelo não bastam para explicar toda a nossa realidade circundante, embora permaneçam, durante quatrocentos anos, na base da nossa cultura, que por eles fica habituada a se organizar, sentir e raciocinar. Na era do processo transnacional da globalização dos fatos histórico-culturais, socioeconômicos e políticos, que, à semelhança de todos os demais, são inter-relacionados e interdependentes, encontramo-nos, segundo observação de Fritjof Capra, "diante de novos paradigmas de análise, de interpretação da realidade, quais sejam: o fim da crença nas verdades absolutas, legitimadoras do status quo, e a interdisciplinaridade" (1996, p. 141). O saber humano é um só. Apenas por razões consideradas didáticas, costumamos dividi-lo em nome de uma pretensa facilidade do aprendizado.

Todavia, nos nossos tempos, a unidade do conhecimento torna-se um dos seus imperativos. Intimamente, associamos semelhante unidade, como assinala Niels Bohr (1961), "à nossa busca de uma compreensão universal, destinada a elevar a cultura humana". Precisamos, então, adotar um modelo de análise orquestral, comunitária, e firmar, numa visão sistêmica, relações entre os diversos aspectos do conhecimento, com vistas a desenvolver o diálogo entre eles, sem a compartimentação dos dados do real, demonstrada pela ótica positivista de causa e efeito. Noutros termos, devemos atentar para a interação entre as áreas, sem deixarmos de assinalar as suas diferenças, num processo em que cada uma contribua para um saber comum. Um perfeito exemplo de tal fenômeno constatamos através das ligações estabelecidas entre a literatura e a ciência histórica. E recorremos à aludida interdisciplinaridade, como um instrumento de explicação articulada do fenômeno literário, em observância ao seu contexto cultural, ao ter em mente, inclusive, que o procedimento interdisciplinar é considerado um novo organum dos estudos acadêmicos.

Por conseguinte, caracterizamos o nosso artigo como analítico-interpretativo, de base bibliográfica interdisciplinar (conexões entre a arte verbal e a ciência histórica). Em virtude disso, a bibliografia que utilizamos para o embasamento argumentativo envolve a teoria, a crítica e a historiografia literária, com ênfase no ideário romântico, do mesmo modo que

\footnotetext{
${ }^{2}$ Atualizamos a ortografia de todas as citações.
} 
envolve a história, em particular a de Portugal. Até porque concebemos a arte da palavra sob a condição de uma forma de entendimento da história, ainda mais quando estamos cientes de ambas possuírem, essencialmente em comum, o código narrativo como elemento estrutural. Aliás, das colaborações que a chamada nova história extrai da teoria literária, o questionamento a respeito da narração é um dos mais expressivos. Com base no pensamento de estudiosos da estirpe do hermeneuta Paul Ricouer (1991), aceitamos que a narrativa historiográfica e a narrativa ficcional, não obstante conservarem características próprias, se achegam em vários pontos e tomam "emprestados", uma da outra, recursos para aperfeiçoarem os fundamentos dos seus enunciados e o diálogo com os seus receptores. Inclusive, são discutidas como gêneros de fronteiras. $^{3}$

Para esse enfoque vários historiadores da nossa contemporaneidade, a exemplo de Hayden White (1995), Peter Burke (2005) e Carlo Ginzburg (1991), se voltam, com vistas a uma reflexão fora do confronto entre narradores e analistas, ao contemplarem duas vertentes de exame em interação: o da literatura e o da história. Os cientistas históricos, ao visarem à ampliação do seu campo temático e com o intuito de não continuar apenas com as narrativas acerca das chamadas grandes personagens, ou com uma história do mundo restrita à biografia dos seus "grandes homens", voltam-se a outras questões, como as mentalidades, a cultura material (casas, mobílias, roupas, alimentos), o inconsciente coletivo, os mitos e as narrativas afins. Interessam-se, numa exploração do potencial que a arte da palavra disponibiliza à história cultural, por gente do povo, mulheres, crianças, jovens, idosos e negros, todos considerados antes ocupação da literatura.

Conforme Ginzburg (1991, p. 188-191), a ficção histórica desencadeia mudanças na historiografia científica, a qual incorpora novas fontes esclarecedoras da vida privada e diária. Esse é o caso de periódicos sobre tal vida e das obras de imaginação, hoje merecedores do status de duas modalidades de documentos históricos. No diálogo entre a arte verbal e a historiografia, Ginzburg (Ibidem) destaca que, nos Oitocentos, certos romancistas adotam para as suas composições a classificação de "História", dado o conceito mais elevado que a última então

\footnotetext{
${ }^{3}$ De 22 a 26 de maio de 1995, como atividade do Centro Álgel Rama de Estudos da Cultura e da Literatura LatinoAmericanas, entidade interdepartamental e interdisciplinar da USP, essa e a UNICAMP realizam, sob a coordenação da Profa. Dra. Lígia Chiappini Moraes Leite, o seminário internacional Gêneros de fronteira: cruzamentos entre o histórico e o literário, cujos trabalhos resultam no livro homônimo de 1998, organizado pelos Profs. Drs. Flávio Aguiar, José Carlos Sebe e Sandra Guardini T. Vasconcelos, todos da USP.
} 
possui. Ademais, semelhantes literatos recorrem ao estilo narrativo da historiografia e aos caracteres atinentes à veracidade das figuras enfocadas pela ciência em tela. Entretanto, o fato se transforma com a ascensão do romance, o qual vem a se tornar, no conhecido dizer de Friedrich Hegel em sua Estética (1835), “a epopeia dos tempos modernos” (1980).

Tanto a literatura quanto a história, até por buscarem, a primeira, intuitivamente e a segunda, cientificamente, ler a humanidade e a sua trajetória, ou explicar o seu percurso pelo mundo, conquistam o centro do debate da contemporaneidade, cuja visão globalizante reduz a Terra a uma aldeia, a dita Aldeia Global, expressão cunhada por Herbert Marshall McLuhan (1971), numa nova ordem planetária, detentora de uma complexidade avessa a uma sociedade excludente. Em face disso, no tempo da globalização, semelhante movimento aprofunda, a um só tempo, a integração e a diversidade cultural dos povos; realça aspectos étnico-nacionais e adquire visibilidade acadêmica com o novo marco conceitual e paradigmático referido, em reflexo à mentalidade cosmopolita, característica do nosso momento histórico, mediante, por exemplo, as relações entre a arte literária e a ciência histórica.

Contudo, já na primeira metade do século XX, alguns pensadores da Universidade, como Alceu Amoroso Lima (2001), ressaltam na Academia a sua natureza de universo de saberes, de círculo de discussões, que precisa estar em constante sintonia com o mundo e evitar, dessa maneira, a formação de sujeitos profissionais fragmentados ou alienados da totalidade das coisas. Isso porque, no pensamento do patriarca da moderna crítica lítero-cultural da América Portuguesa, comprovamos a missão da Universidade a partir do seu lugar de humanização global entre as pessoas, as classes e as nações. E, na época presente, mais do nunca, a Academia se caracteriza por ser um meio de busca do diálogo, das identidades e diferenças, da troca de experiências, pelo intercâmbio de conhecimentos atualizados e da interdisciplinaridade. Nesse sentido, a ficção histórica, ${ }^{4}$ surgida dentro do Romantismo na Europa, ao reconstituir pensamentos, ambientes e cotidianos, prefigura o atual estudo das ciências humanas sobre as mentalidades. E no contexto do primeiro período estilístico do século XIX luso, tal gênero literário configura, com Alexandre Herculano e a ficção burguesa de atualidade, um dos marcos da prosa moderna em língua portuguesa.

Cabe-nos lembrar que Portugal é caudatário dos grandes polos ocidentais. Nele, não obstante o esforço da intelectualidade para acompanhar as diretrizes europeias, uma narrativa como Viagem à roda do meu quarto (1749), de Xavier de Maistre, após o advento dos

\footnotetext{
${ }^{4}$ Trata-se da ficção que abrange recriação e reinterpretação de matérias concernentes à história.
} 
Oitocentos, ainda vai servir de modelo a uma das pioneiras obras românticas: o romance de atualidade Viagens na minha terra (1846), de Almeida Garrett. Portanto, é compreensível que, no Século das Luzes, o gênero romanesco quase não encontre cultores naquele país ibérico. Tal se deve ao fato de que, nas letras lusitanas, se perde a novela cavalheiresca, bucólica e sentimental, além do que não faz escola a narrativa didático-alegórica, apesar da preferência do público da época por essa última manifestação novelesca. E, ao abordarmos o romance romântico, observamos a sua indiferenciação inicial relativamente à novela.

Em semelhante domínio genológico, Herculano notabiliza-se na condição de um fundador, o qual descreve trajetória, dentro e fora da sua nação de origem (pois sofre o exílio político decorrente das suas ideias antiabsolutistas), para criar a forma e a substância da prosa burguesa lusófona, com uma herança cujos ecos, tanto na pátria de Camões quanto no alémmar, chegam à nossa contemporaneidade. Assim, no artigo ora apresentado, ao contrário de uma tradição que privilegia a faceta científica do intelectual aqui inserido desde o título, temos por objetivo enfocar a prosa moderna de Herculano enquanto autor lítero-histórico.

\section{A literatura e a história segundo Herculano}

No nosso idioma, a ficção histórica, rebento da prosa gótica e de cavalaria, nasce com a publicação, em jornais e revistas, de novelas e contos posteriormente compilados e agrupados no livro Lendas e narrativas (1851), de Alexandre Herculano. A mesma ficção também nasce com o lançamento dos seus três romances: Eurico, o presbitério (1844), O bobo (1878) e $O$ monge de Cister (1848). ${ }^{5}$ Torna-se moda no período romântico, circula em vernáculo ainda na última metade dos Oitocentos e, em moldes diferentes, nos tempos vindouros. Particularmente, as Lendas e narrativas são colhidas pelo medievalista português na Península Ibérica, enquanto recuperação de dados da memória nacional, sob a forma de histórias folhetinescas, recriadas de fontes primárias: os antigos nobiliários, ou Livros de linhagens (séc. XIII e XIV), e os primeiros relatos historiográficos lusitanos, ou Cronicões (1429), ainda atrelados ao lendário. ${ }^{6}$ Semelhantes folhetins de Herculano, a princípio, apresentam enredos transcorridos em meio a

\footnotetext{
${ }^{5} \mathrm{O}$ monge de Cister vem a lume parcialmente na revista $O$ Panorama em 1841e, em volume, em 1848; Eurico, o presbítero é estampado em parte em O Panorama e na Revista Universal Lisbonense em 1843 e, em volume, em 1844; $O$ bobo é publicado em $O$ Panorama em 1843 e, em volume, postumamente, em 1878, além de circular, em vida de Herculano, numa edição pirata brasileira, de 1866.

${ }^{6}$ Exceção fazemos a um texto/pretexto para muitas das mais caras questões herculanianas, "O pároco de aldeia", e às impressões de viagem "De Jersey a Granville". Ambos são relatos de atualidade e narrativas-ensaios, cuja teorização encontramos em Friedrich Schlegel (apud FERRAZ, 1987), autor do romance-manifesto Lucinda (1799), além de mentor e maior teórico alemão do Romantismo.
} 
um povo que subjuga e depois assimila a cultura clássico-romana. Falamos dos membros do reino germânico-visigótico na Ibéria, durante a invasão dos povos norte-africanos mouros, de quem deriva um termo originalmente pejorativo - moreno - e os quais, de maneira genérica, são árabes, berberes (do latim barbarus, ou estrangeiros), negros islamizados e até escravizados, ou quaisquer misturas entre eles.

Herculano, poeta, ficcionista, memorialista, teatrólogo, ensaísta, jornalista polemista, paradigma dos arquivistas e bibliotecários lusos, pioneiro historiador científico em vernáculo, pensador crítico, cidadão e representante público ético, educador prático e democrático, é um polígrafo que aborda também o seu fazer com as palavras, um dos interesses atuais da sua produção histórico-literária, já que a metalinguagem é um traço da prosa moderna, surgida mediante princípios técnicos como o distanciamento reflexivo na relação autor/narrador/leitor e sobre o ato criador; noutras palavras: a ironia romântica alemã. Essa, em relação ao Ancien Régime, é um código moderno de ruptura, preconizado pelos irmãos Friedrich e August Schlegel, sobretudo nos Fragmentos (1798) do primeiro, estampados na revista Athenäum, a partir da filosofia da subjetividade, consciência e realidade empírica de Johann Fichte.

Desvelado leitor e discípulo de Friedrich Schiller, ${ }^{7}$ Immanuel Kant e outros intelectuais germânicos, Herculano corporiza o espírito teutônico, haja vista a recorrência, na obra de tal lusitano, de dois procedimentos complexos e justapostos de expressão: a aludida ironia romântica, a qual, na Alemanha, tem E.T.A. Hoffmann por mestre, e o apelo estratégico ao leitor para a narração, sob a perspectiva daquele que Norman Friedman, em $O$ ponto de vista na ficção (apud LEITE, 1994, p. 26) e no âmbito da subjetividade autoral, denomina autor/narrador onisciente intruso. E para a estudiosa portuguesa Maria de Lourdes Ferraz, em A ironia romântica:

O estatuto autoral do narrador foi comum nos séculos XVIII e XIX, embora já tivesse um grande peso na novelística de caráter irônico, nomeadamente em D. Quixote (1605), de Cervantes. Para os românticos, o autor/narrador apresenta-se como uma necessidade e a produção escrita, como ação preferida, a par do contributo imaginativo do leitor. Aqui, o narrador aparece sob a figura de um autor, fato que concede ao texto caráter pessoal de missão desempenhada e se coaduna com uma consciência romanesca autocêntrica. O jogo irônico incide sobre o sujeito enunciador, paradoxalmente, realidade (autor) e ficção (narrador) (FERRAZ, 1987, p. 66-71).

O retromencionado autor/narrador, em toda a obra prosística herculaniana, com graves e densas reflexões interruptivas do fluxo do relato, carregadas de teoria e erudição, ou com

\footnotetext{
${ }^{7}$ Como historiador, é o autor de História da separação dos Países Baixos (1788) e História da Guerra dos Trinta Anos (inacabada, 1791-1793).
} 
comentários jocosos, até autoirônicos, autozombeteiros, de um humor metalinguístico, fala de si, da própria feitura literária e, por consequência, do jogo dialético ficção/realidade, veracidade/verossimilhança da ilusão representativa, sempre no sentido de fornecer subsídios para apurar o gosto do público, conforme o preconizado por F. Schlegel. Como criador literário e historiador romântico, Herculano comenta a integração entre a matéria histórica e a ficcional. De onde acatarmos as seguintes conclusões sobre ele:

O seu individualismo romântico traduz-se na inamovível presença da pessoa do autor, quando não como objeto principal do interesse, ao menos como sujeito acima de todos interessado na ação, apresentando a personagem, expondo a ideia, fazendo o comentário, exprimindo o louvor ou a repreensão. Na própria historiografia, esse individualismo se afirma, na seleção, exposição e comentário dos fatos, sempre na subordinação a uma tese em que se afirma o ideal político, social ou religioso do historiador (CIDADE, 1960, p. 123).

Como romântico que era, Herculano pretende acima de tudo interessar o leitor, mas interessar apaixonadamente, pelos problemas que ele considera fundamentais. Não lhe basta uma simples adesão intelectual, uma simpatia entre o espírito do leitor e as suas ideias. Pretende criar uma atmosfera emotiva que tenha a força suficiente para conduzir à ação em defesa de certos ideais (NIZZA DA SILVA, 1964, p. 15-16).

A ficção não contradiz o ensaio, a história não nega o romance, nem esse desfigura aquela - e o autor de $O$ monge de Cister projeta-se igualmente na sua obra de imaginação e nos seus trabalhos rigorosamente críticos (TRINDADE, 1965, p. 4).

A ficção e a historiografia de Herculano são as duas faces de um mesmo e amplo projeto histórico-cultural. A nossa preocupação deve centralizar-se na descaracterização do privilégio que alguns críticos conferiram a partes isoladas da obra de Herculano, em detrimento de outras. Dessa forma, ele não foi acima de tudo um historiador; também não foi um ficcionista preocupado com a história de Portugal, ou um crítico que lutou pela organização das Instituições Portuguesas. Foi tudo isso ao mesmo tempo (DURIGAN, 1983, p. 39).

De feição histórica, lendária e de atualidade, a narrativa herculaniana está voltada para si através de elementos pré- e pós-textuais (prefácios e posfácios), de epígrafes, notas de rodapé, artigos e digressões. Logo, assume uma postura autorreflexiva, cujo construto engendra a metalinguagem e aponta para as articulações mantidas por contos, novelas e romances com o aparato cultural que os sustenta, viabiliza, interpreta e, historicamente, contextualiza. Tal postura estabelece o grau de distanciamento ou de adesão do autor/narrador no que diz respeito tanto à matéria diegética, seja histórica ou não, quanto à produção do seu relato, cujo fio é, como declaramos, cortado por digressões interpostas entre o leitor e o texto. 
Em semelhante esfera, a aludida narrativa-ensaio, cultivada no século XVIII por Henry Fielding em Tom Jones (1749) e por Laurence Sterne em Tristam Shandy (1760); no século XIX, por Liev Tolstoi em Guerra e paz (1863-1869) e, em vernáculo, por Almeida Garrett em Viagens na minha terra (1846), por Camilo Castelo Branco em várias obras e por Machado de Assis nos contos e romances da sua segunda fase (isso para ficarmos só com esses exemplos), já se encontra nos cancioneiros provençais, nos quais Dante calca a construção de Vita nuova (1294), em que a estrutura equilibra narrativa, comentário de caráter ensaístico e poesia. Contudo, é nos tempos modernos, com a eclosão da crise da representatividade na arte, que o caráter metalinguístico se torna um dos traços marcantes de todas as manifestações artísticas, visto que, na nossa era, a concepção de arte não é mais a de sentimento e expressão, mas sim a de consciência e construção. Daí a presença, na contemporaneidade, de uma ficção que:

[...] se cansa de fingir-se neutra e resolve também assumir o relativo e o subjetivo do contar. Uma ficção que, por isso mesmo, inventa ou retoma ao passado (é o caso da volta à moda do narrador onisciente intruso) técnicas não ilusionistas para dar lugar às múltiplas leituras do real (LEITE, 1994, p. 85).

Como sabemos, a arte verbal contemporânea é receptiva a diversos matizes comunicativos, pois, na escrita criativa, vemos elementos de outros códigos estéticos, como o cinematográfico. Lembramos que técnicas lítero-narrativas utilizadas nos séculos XVIII e XIX perdem eficácia diante de um público acostumado à ficção através de veículos do tipo televisivo-cinematográfico. E Herculano, do qual algumas narrativas são adaptadas para múltiplos substratos de circulação, como a música (canto lírico), ou programas audiovisuais, como que se antecipa à referida tendência.

No seu romance histórico Eurico, o presbítero, mediante cenas movimentadas, a exemplo do rapto da amada negada e a subsequente busca, para cuja descrição se acumulam verbos de ação, bater, correr, atacar, romper, avançar, retroceder, arremessar ou derrubar, o nosso autor realiza "uma feliz reconstituição de uma época de alta tensão de aventuras cavaleirescas, com o seu odor de far-west" (MOISÉS, 1981, p. 139). Ali, a perseguição aos islâmicos mouros pelos cristãos podemos comparar a uma caçada cinematográfica em Hollywood. A saga de Eurico, primeiro super-herói ibero-americano, um semideus entre os homens, recebe tradução intersemiótica, também, para a História em Quadrinhos e para o teatro, inclusive com versão cênica em 1870 para uma ópera homônima do compositor lusitano Miguel Ângelo Pereira. 
Ademais, segundo o roteirista português Alexandre Borges (2016), Eurico, o presbítero presta-se perfeitamente a uma superprodução cinematográfica do gênero épico de guerra, bem ao gosto das gerações antigas e das novas, as quais se movem entre diferentes suportes artísticos, o da literatura impressa, o da sétima arte e afins, com apreciação de películas de temática medieval, fato ilustrado por um filme de Mel Gibson, Coração valente (1995), nomeado em Portugal Desafio do guerreiro. Tudo isso porque, nessas fitas, que unem o histórico e o lendário, há a presença de bravos cavaleiros, hábeis arqueiros, românticos e generosos foras-da-lei, como Hobin Hood, monges, castelos, cenas de batalhas, de lutas de capa e espada; de paixão amorosa, sobretudo do par de protagonistas, além da presença de povos outros, considerados exóticos, como os mouros.

No entanto, ao seu tempo e no prefácio (advertência) da primeira edição das Lendas $e$ narrativas, Herculano as considera apenas como "as primeiras tentativas do romance histórico que se fizeram em língua portuguesa". No prefácio da segunda edição (1858), o autor da publicação História de Portugal (1846-1856) faz uma crítica as suas próprias composições, ao julgá-las "desordenadas tentativas", "simples marcos" lítero-historiográficos. Mas, ainda quando, com esse julgamento de valor, ele se antecipa às críticas mordazes que a prosa medievalista de imaginação vai receber de um Eça de Queirós ${ }^{8}$ e como observa Harry Bernstein (1983, p. 142), " "não interessa quão modesta ou depreciativamente Herculano avalia o seu trabalho", ao que acrescentamos que também não importa o que diz Vitorino Nemésio (1970), para quem tais relatos constituem matérias excrescentes e marginais à ciência histórica herculaniana.

Isso porque as Lendas constituem textos bem cuidados, pelo relevo literário, pela sedução novelesca, pela reconstituição de época. E, assim como toda a novelística do seu autor, devem ser encaradas como uma faceta espontânea, criativa, da atividade profissional de Herculano, o qual procura delimitar as áreas epistemológicas imbricadas na sua biografia intelectual. Até porque o ficcionista dedica-se a uma história diferente da científica e volta-se para o público em geral. De onde o criador de Lendas e narrativas, no artigo jornalístico "A

\footnotetext{
${ }^{8}$ O seu romance ruralista A ilustre casa de Ramires (1900), ao ser encarado sob a ótica do historicismo, se singulariza como produção detentora, em mise en abîme, de uma novela (A torre de D. Ramires) que reproduz, ironicamente, a técnica da narrativa introduzida em Portugal por Herculano. Mas o romance queirosiano também nos sugere que, no fundo, Eça mima a ficção histórica, acredita ou quer acreditar no que ela contém de épico (a heroicidade, a capacidade empreendedora, o sentimento de honra), como contribuição artística para o despertar das energias adormecidas do pais; o resgate do orgulho nacional, tão desprestigiado. Cf. Ramos Júnior, 1993, p. 19-54.

${ }^{9}$ Tradução nossa.
} 
velhice", publicado na revista O Panorama (N. 170/08/1840), entender que a ficção histórica pode ser igual ou até maior que a historiografia. Vejamos:

\begin{abstract}
Novela ou história - qual dessas duas coisas é mais verdadeira? Nenhuma, se o afirmarmos absolutamente de qualquer delas. Quando o caráter dos indivíduos ou das nações é suficientemente conhecido, quando os monumentos, as tradições e as crônicas desenharem esse caráter com pincel firme, o novelista pode ser mais verídico do que o historiador: porque está mais habituado a recompor o que é morto pelo coração do que vive, o gênio do povo que passou pelo do povo que passa. Então de um dito ou de muitos ditos, ele deduz um pensamento ou muitos pensamentos, não reduzidos à lembrança positiva, não traduzidos, até, materialmente; de um fato ou de muitos fatos deduz um afeto ou muitos afetos, que se revelaram. Essa é a história íntima dos homens que já não são; essa é a novela do passado. Quem sabe fazer isso chama-se Walter Scott, Victor Hugo e Alfred De Vigny, e vale mais e conta mais verdades que meia dúzia de bons historiadores (apud MARINHO, 1992, p. 98).
\end{abstract}

A novela, o romance histórico, então, pode revelar "verdades", inclusive com mais intensidade do que a história, que toma por base a pesquisa e o conhecimento objetivo. Igualmente, pode ser a forma intuitiva, indizível, do discurso da história e da sua correspondente investigação; possibilita a fixação de características subjetivas de um tempo, da sensibilidade e pensamento de outras eras pela apreensão do espírito do povo, ou, para os românticos, do Volksgeist, que o ficcionista atualiza no contexto histórico.

O nosso intelectual português concebe a história como discurso verdadeiro e a literatura como discurso verossímil, ao mesmo tempo em que relativiza o verdadeiro, pois a ficção contém a "verdade" íntima de uma nação, que a ciência parece não captar. Em narrativas como Eurico, o presbitero, $O$ bobo, ou $O$ monge de Cister, o seu criador não pretende fazer história, e sim expressar o Volksgeist, não em antagonismo, mas em complementaridade à ciência histórica. Assim é que podemos descobrir, "sob a multiplicidade dos interesses e talentos do intelectual, uma unidade de concepção. O contador de histórias românticas e o intérprete da história nacional estão unidos pela mesma visão crítica” (MACHADO, 1997, p. 12).

Historiador profissional, Herculano acredita na maior eficácia do processo ficcional por esse tornar viva a matéria narrada, não obstante o lugar-comum de que o medievalista lisboeta se comporta como vocacionado cientista histórico mesmo quando produz narrativas literárias. A realidade prova o contrário, como exemplificam os seus três romances. Esses, embora centrados numa escala de grandes momentos peninsulares, a saber, a invasão muçulmana, a fundação de Portugal e o pós-guerra luso-castelhana, continuam romances: nascem do desejo pessoal de intrigar, poetizar, comover. O que acontece é um feliz compromisso entre a erudição do historiógrafo e a imaginação do ficcionista. 
Aliás, é por via das propensões para a literatura de imaginação que o romancista lusitano é levado para a ciência, como ele confessa no prefácio do seu livro História da origem e estabelecimento da Inquisição em Portugal (1854-1859), em que ele nos dá uma demonstração do seu patriotismo lúcido, não cego e ufanista; da sua prática histórico-literária combativa, ao revelar o seu objetivo de denunciar, como exemplo negativo para sociedade da época, um período sombrio da história pátria, marcado pelo abuso de poder, o que representa a herança reflexiva da historiografia oitocentista recuperada pela nossa contemporaneidade:

Levados pelas nossas propensões literárias para os estudos históricos, era, sobretudo, por esse lado que podíamos ser úteis a uma causa a que estamos ligados, rememorando um dos fatos e uma das épocas mais célebres da história pátria, fato e época em que a tirania, o fanatismo, a hipocrisia e a corrupção nos aparecem na sua natural hediondez (HERCULANO, s.d., p. 15).

E na presente manifestação do ideário romântico, o romance histórico é a expressão das raízes nacionais mais profundas, antropológicas, num procedimento quase místico de unificação da alma do romancista à do povo. Herculano estabelece uma verdade interiorista $\mathrm{e}$ reconhece a dialética entre o verdadeiro e o verossímil. Numa obra pródiga em alusões metaliterárias como são as Lendas e narrativas, o seu autor nos dá uma oportuna digressão na qual apresenta uma saída para o intrincado jogo dicotômico entre ficção e realidade, verossimilhança e veracidade, saída essa localizada no conto "O bispo negro". Semelhante narrativa é uma releitura e reescrita da lenda da nomeação, por D. Afonso Henriques e em desacordo com o Papa, de uma autoridade eclesiástica negra em Portugal, país exemplo de precoce autoimagem nacional entre os reinos europeus:

O príncipe de Portugal Afonso Henriques, depois de uma revolução feliz, tinha arrancado o poder das mãos da sua mãe. Se a história se contenta com o triste espetáculo de um filho condenando ao exílio aquela que o gerou, a tradição carrega as tintas do quadro, pintando-nos a desditosa viúva a arrastar grilhões no fundo de um calabouço. A história conta-nos o fato: a tradição, os costumes. A história é verdadeira, a tradição verossímil: e o verossímil é o que importa ao que busca as lendas da pátria (HERCULANO, 1960, p. 253-254).

Verificamos, assim, que a proposta herculaniana está voltada não só para reconstituição do passado histórico da pátria lusitana, mas principalmente para a reconstituição do seu passado mítico-lendário, já que a reelaboração literária dos mitos, das lendas nacionais, configura “outra forma de trazer o passado do país para o presente, sem ferir a história, que faz parte de outro campo do conhecimento" (OLIVEIRA, 1995, p. 63). E também é no supracitado "O bispo negro" que lemos numa nota de rodapé inicial: “A sé velha de Coimbra é, no todo ou na máxima 
parte, uma edificação dos fins do século duodécimo; mas aceitamos aqui a tradição que lhe atribui uma remotíssima antiguidade" (HERCULANO, 1960, p. 253). Essa declaração do autor/narrador nos revela que no conto enfocado se entrecruzam duas vozes: por uma parte, temos o narrador de tradições; por outra, o historiador que decompõe os seus materiais exatamente para diferenciar o que é história do que é lenda, atitude que, como sabemos, Herculano defende quando, por exemplo, se empenha em provar a inverdade histórica do milagre de Ourique, ou a aparição de Cristo a D. Afonso Henriques.

É a voz do historiador, que, após o final de "O bispo negro", elabora uma longa nota na qual refuta a base histórica do incidente, ao tratar a narrativa como fantasiosa e ao rastrear a sua origem: "A lenda precedente é tirada das crônicas de Acenheiro, rol de mentiras e disparates, publicado pela Academia" (HERCULANO, 1960, p. 266). Dessa forma, estamos diante de um conto em que a tradição é retomada pela literatura e, ao mesmo tempo, emoldurada por observações que revelam a não veracidade histórica do que é relatado.

Entretanto, no que tange, especificamente, à descrição de costumes e objetos, a preocupação de Herculano com o real verificável chega aos mínimos detalhes. A título de exemplo, refiramos que, numa novela das Lendas e narrativas, qual seja, "Arras por foro d'Espanha”, são tantas as notas de rodapé a indicar a fonte, o documento comprovativo da exatidão do quadro pintado, que, numa delas, o autor/narrador acha oportuno informar: "Para não enfadarmos os leitores com um sem número de notas, declaramos por uma vez que todos os costumes e objetos que descrevemos são exatos e da época, porque para tais descrições nos fundamos sempre em documentos ou monumentos (HERCULANO, 1960, p. 80).

Por outro lado, sabedor, como visto, que na ficção o que conta é a verossimilhança e não a verdade histórica, factual, Herculano, numa nota da citada novela "Arras por foro d'Espanha", apressa-se a fazer a sua defesa de possível acusação de inverossimilhança de uma cena que ele, pela boca do narrador, descreve. Para tanto, apresenta argumentos e provas que tornam verossímil o incidente inventado, conferem à cena fictícia um "efeito de verdade" e similaridade com fatos da vida real:

Aqueles que não conhecerem as opiniões, estado de civilização e costumes da Idade Média medirão o tesoureiro-mor Dom Judas por um ministro da fazenda moderno, como, se não nos engana a memória, lhe chama com ignorância deliciosa o Marquês de Pombal em uma lei sobre os cristãos-novos, e acharão inverossímil a cena antecedente, posto que esteja bem longe disso. A falta de cristãos habilitados para tratarem matérias de fazenda pública obrigou os reis portugueses a esquecerem a lei das cortes de 1211 que os inibia de empregarem judeus no seu serviço. [...] Junte-se a isso o caráter de Dona Leonor Teles, tão excelentemente pintado pelo grande poeta- 
cronista (histórico) Fernão Lopes, e poder-se-á avaliar devidamente a verossimilhança dessa cena de imaginação, no meio de outras cenas da vida real desses tempos (HERCULANO, 1960, p. 89-90).

Outrossim, a atestação da veracidade da narrativa aparece na prosa ficcional de Herculano enquanto a retomada, por parte dos literatos românticos (não só dos ficcionistas históricos), do consagrado tópico da "legitimação" do enredo, que consiste em firmar a autenticidade dos textos mediante a invenção de fontes, como antigos manuscritos encontrados em conventos e bibliotecas.

E na qualidade de último recurso de "legitimação" do enredo, os românticos apelam simplesmente para a antiguidade da tradição, conforme ocorre em um conto de Lendas $e$ narrativas, intitulado "A dama pé-de-cabra", relato no qual, logo na primeira parte, o autor/narrador assume, sem subterfúgio, que reconta (e assim recupera) uma tradição, uma história anônima jogralesca do século XI, ao tempo em que simula uma situação de oralidade diante da assembleia presente. Tal "legitimação" também consiste na dramatização do Eu enunciador no enunciado, como ilustramos abaixo, e caracteriza a ironia romântica, cujos adeptos valorizam a tradição oral, permitem-se o luxo de saltar por cima dos períodos clássicos e apregoam-se herdeiros diretos dos trovadores e contadores de outrora. Vejamos:

\footnotetext{
Vós os que não credes em bruxas, nem em almas penadas, nem em tropelias de Satanás, assentai-vos aqui ao lar, bem juntos ao pé de mim, e contar-vos-ei a história de D. Diogo Lopes, senhor de Biscaia.

E não me digam no fim: - "não pode ser".

- Pois eu sei cá inventar coisas dessas? Se a conto, é porque a li num livro muito velho. E o autor do livro velho leu-a algures ou ouviu-a cantar, que é o mesmo, a algum jogral em seus cantares.

É uma tradição veneranda; e quem descrê das tradições lá irá para onde o pague. Juro-vos que, se me negais essa certíssima história, sois dez vezes mais descridos do que São Tomé antes de ser grande santo. E não sei se eu estarei de ânimo de perdoarvos como Cristo the perdoou. Silêncio profundíssimo; porque vou principiar (HERCULANO, 1952, p. 217).
}

Nesse âmbito, o nosso autor, no seu artigo "Novelas de cavalaria portuguesas", integrante do volume IX dos seus Opúsculos, confessa que "era quase lei entre os romancistas dar uma origem misteriosa, ou ao menos remota, ao fruto das suas imaginações (HERCULANO, p. 13, 1909). Semelhantes fontes, via de regra, são mencionadas em prólogos ou epílogos e o autor empírico apresenta-se como tal para imprimir veracidade à narrativa. $\mathrm{Na}$ fase de autoafirmação do romance, é muito comum que os ficcionistas se apresentem como 
copistas de velhas crônicas históricas; conhecedores de casos verídicos de que são reprodutores, relatores fidedignos.

Aqui, o narrador se reveste da figura do autor e pretende ser o porta-voz do discurso confiável dos enredos. A "verdade", então, como no caso de "A dama pé-de-cabra", corresponde ao que assevera o autor/narrador. Tal atitude de Herculano nos remete a Alfred de Vigny (1980), que, em seu romance histórico Cinq-Mars (1826), exatamente no prefácio da obra, com o ensaio "Reflexions sur la vérité dans l'art", aponta, no ficcionista histórico, duas necessidades que parecem opostas, mas que se confundem, ao seu ver, numa fonte comum: uma é o amor à verdade, outra, o amor ao fabuloso. ${ }^{10}$

Em Herculano, a instância legitimadora da narrativa pode mostrar uma conduta chistosa, entre a graça e a zombaria (do leitor), como observamos no excerto transcrito de "A dama péde-cabra". Ali o autor/narrador parece nos lembrar que tudo não passa de ficção, de uma encenação, a qual ele não só reconhece como ironiza. Maria de Lourdes Ferraz (1987, p. 3940) aponta o fato de que "a ironia romântica, como discurso literário, seja a sua prova máxima e a sua própria paródia, qual seja, a do Romantismo", quando sabemos que a paródia é o canto paralelo em nível etimológico, a reverência às avessas, uma homenagem a gêneros personalíssimos, cujas características são facilmente identificadas. Igualmente aqui, o texto literário revela a autoironia em relação à verdade histórica, o que podemos ver na seguinte passagem de uma lenda desenvolvida por Herculano em "A abóboda":

\begin{abstract}
Essa é, em breve resumo, a história de David Ouguet, tirada de uma velha crónica, que, em tempos antigos, esteve em Alcobaça encadernada em um volume juntamente com os traslados autênticos das cortes de Lamego, do Juramento de Afonso Henriques sobre a aparição de Cristo, da Carta de feudo a Claraval, das Histórias de Laimundo e Beroso, e de mais alguns papéis de igual veracidade e importância, que, por pirraça às nossas glórias, provavelmente os castelhanos nos levaram durante a dominação dos Filipes (HERCULANO, 1952, p. 175).
\end{abstract}

A propósito, ao discutir a questão da veracidade em um poema narrativo garrettiano, Dona Branca ou a conquista do Algarve (1826), em que as personagens são extraídas da história de Portugal e o enredo se emaranha em incidentes fabulosos, Cleonice Berardinelli recorre ao supracitado jogo humorístico de Herculano, com o objetivo de justificar o caso de Garrett poder

\footnotetext{
${ }^{10}$ No original: "Nous trouverons dans notre coeur plein de trouble, où rien n'est d'accord, deux besoins qui semblent opposés, mais que se confondent, à mon sens, dans une source commune: l'un est l' amour du VRAI, l'autre l'amour du FABULEUX". In. VIGNY, Alfred de. Cinq-Mars. Paris: Gallimard, 1980, p.24.
} 
expor o seu subjetivismo (que a ficção histórica comporta), além de lhe permitir estilizar e fantasiar, na mencionada criação literária, os fatos passados:

Como condenar o poeta por fantasiar a história, se o mais insigne historiador do seu
tempo, fundamente marcado pela probidade, pelo mais rigoroso respeito às fontes, usa
de ampla liberdade quando assume o papel de romancista ou contista, interpelando o
leitor com ironia, a afirmar que todos os textos históricos em que se baseou são
absolutamente dignos de fé, divertindo-se em compartilhar o jogo com talvez a
maioria dos que o leem e enganar ao menos uns quantos, aqueles que ignoram que as
Cortes de Lamego são uma lenda ou que não se deve piamente acreditar nas Histórias
de Laimundo e Beroso? É curioso que seja Herculano, definido principalmente pela
severidade, pelo ar sério que se nota invariavelmente nas suas fotografias, pela
gravidade das suas posições, e não o seu amigo onze anos mais velho, sempre
elegantíssimo e parecendo, até por isso mesmo, mais superficial, que seja Herculano,
repito, aquele que, ao longo das suas Lendas e narrativas ou dos seus romances $O$
bobo e $O$ monge de Cister, interrompe com frequência a narrativa, passando de
narrador a comentador do narrado, muito a sério, sobretudo ao fazer o confronto entre
passado e presente, mas também a rir, desmentindo a autenticidade do narrado
(BERARDINELLI, 1999, p. 103).

Em tal esfera, no romance histórico $O$ monge de Cister, ao mesmo tempo em que insiste nas atestações de veracidade da sua narrativa, o autor/narrador remete-nos para o descrédito das mesmas, porque, embora sempre bem documentado naquilo que escreve, sabe (pois ele próprio diz) que na literatura o verossímil é o que importa. ${ }^{11}$ É que o verossímil, na prosa de ficção, se impõe pela natureza da obra, por sua coerência interna, pela logicidade do enredo, o que o torna acreditável para o leitor, enquanto a narrativa inverossímil necessita de recursos externos, como nos sugere o fragmento abaixo, pleno de autoironia:

Se esse livro fosse uma dessas invenções destinadas unicamente para abreviar o mais cruel martírio do ocioso, a maldição da sua existência, pediria a arte que deixássemos o leitor parafusar à solta acerca do passageiro arruído que se travara no adro. Não o consente, porém, a ordem da narrativa que nos serve de texto. O autor da encarquilhada e venerável crônica monástica ou ignorava ou desprezava as destrezas que dão vida e relevo às vãs ficções de noveleiros e que a verdade, por si mesma bela, rejeita com abominação. Contou as coisas como elas foram, direitamente, singelamente, sem refolhos, sem armadilhas. Seguindo-o passo a passo, a nossa narrativa é como a dele inartificiosa e simples (HERCULANO, 1952, p. 205).

Ainda no post-scriptum de $O$ monge de Cister ou a época de D. João I, numa autoironia concernente à veracidade da narrativa, o seu criador satiriza a gritante assincronia entre a temporalidade da produção do romance histórico e a temporalidade da fábula romanesca, ou entre a época do romancista e a época representada, visto que, nesse caso, o autor/narrador é mediado, ou seja, não tem acesso direto à realidade epocal e sim à fonte, com a qual, ao

${ }^{11}$ Cf. “O bispo negro”. In. Lendas e narrativas, 1952, p. 253-254. 
contrário de uma relação harmoniosa ou até de uma submissão da ficção, Herculano apresenta, por vias humorísticas, uma tensão criativa com a referência da história:

\begin{abstract}
Primo: Uma das regras capitais da verdadeira arte histórica é que as testemunhas irrecusáveis de qualquer sucesso vêm a ser aquelas que vivem três séculos postfactum. Ora, o autor dista da época de D. João I quatrocentos anos bem medidos. Logo, na hipótese do Monge, é de per si autoridade suficientíssima.

Secundo: A precedente narração foi tirada, a bem dizer textualmente, de um manuscrito que estava no mosteiro de ${ }^{* * *}$ da comarca de $* * *$ da província de*** e que só o autor teve a fortuna de ver. Para que serviriam, pois, citações, notas, emburilhadas? A coisa é de uma autenticidade irrepreensível (HERCULANO, s.d., 230-231).
\end{abstract}

Em $O$ bobo, Herculano (sempre em diálogo com o leitor) nos sugere, através da autoironia para com o tópico da veracidade da narrativa, que essa, mesmo ao se apoiar em suporte histórico, não esconde o seu estatuto ficcional. E com ele o autor/narrador ainda joga (quem não entrar no jogo do romancista corre o risco de perde o lance): "Provavelmente o leitor deseja saber o que é feito de Dom Bibas e das mais personagens dessa importantíssima e mui verdadeira história. Dir-lho-emos em breves palavras" (HERCULANO, 1967, p. 180). E chega a nos dar, espirituosamente, a própria definição de verossimilhança e de veracidade: "Coisa incrível, por certo, mas verdadeira como a própria verdade. Palavra de romancista!" (HERCULANO, 1967, p. 23).

Como nas demais narrativas herculanianas, em $O$ bobo, o ficcional invade o histórico e o histórico invade o ficcional: as figuras de D. Teresa, D. Afonso Henriques, Fernando Peres, que é o Conde de Trava, e Egas Moniz, como sabemos, são históricas, bem assim o castelo de Guimarães. Porém, as figuras do bufão D. Bibas, de Garcia Bermudes e Dulce, além da trama amorosa que envolve esses dois últimos e Egas Moniz Coelho, ou a vitória na célebre batalha da Independência, devida, segundo a narrativa, muito mais às vinganças pessoais de D. Bibas e de Egas Moniz Coelho, pertencem ao plano da ficção. Assim, só podemos encarar a probidade histórica contida na seguinte nota de rodapé de $O$ bobo como mais uma inversão satírico-irônica do autor/narrador no que tange à sua própria condição de historiador erudito, o qual se manifesta no romance através de um elemento exterior (nota de rodapé informativa) para criar uma ilusão de veracidade:

Fique dito por uma vez que todos os nomes que empregamos, cenas que descrevemos, costumes que pintamos são rigorosamente históricos. Fácil nos fora reunir esse romance num pélago de citações; E não seria ela ridícula no humilde historiador de um humilíssimo truão? (HERCULANO, 1967, p. 32) 
No romance histórico Eurico, o presbítero, não tem lugar a graça autoirônica no tópico da veracidade textual, que agora comparece de modo sério-estético. ${ }^{12}$ À guisa de exemplo, podemos mencionar que, no prefácio da obra, o seu criador fala da existência de um códice pergaminhático que origina não só a matéria diegética do Eurico, mas também o relato de $O$ monge de Cister:

[...] o pensamento dela foi despertado pela narrativa de certo manuscrito gótico afumado e gasto do roçar dos séculos, que outrora pertenceu a um antigo mosteiro do Minho. O monge de Cister, que deve seguir-se ao Eurico, teve, proximamente, a mesma origem (HERCULANO, 1963, p. 42-43).

Embora aponte a fonte de Eurico, o presbitero, o autor/narrador assume, numa nota de rodapé, a relatividade do valor de verdade de um texto, ao pretender, a um só tempo, manter o caráter de exemplaridade e de "verdade" da sua obra e explicitar a discordância entre o seu discurso e os dados históricos conhecidos:

\begin{abstract}
"Nas mil tradições diversas, quer antigas, quer inventadas em tempos mais modernos, sobre o modo como se constituiu a monarquia das Astúrias, procurei cingir-me, ao menos no desenho geral, ao que passa por mais proximamente histórico. Todavia, cumpre advertir que Pelágio viveu, segundo todas as probabilidades, em tempos um pouco posteriores à conquista árabe, e que a morte de Opas e de Juliano na batalha de Cangas de Onis, sucesso narrado por alguns escritores, tem sobrados caracteres de fabulosa. [...] A minha intenção, porém, foi, como já notei, pintar os homens da época de transição digamos assim, dos tempos heróicos da história moderna para o período da cavalaria, brilhante ainda, mas já de dimensões ordinárias. Desse modo, sendo hoje dificultoso separar, em relação àquelas eras o histórico do fabuloso, aproveitei de um e de outro o que me pareceu mais apropriado ao meu fim (HERCULANO, 1963, p. 229).
\end{abstract}

Nessa linha de abordagem, Maria de Fátima Marinho, em um artigo denominado “(Re) lendo D. Branca", destaca o que se segue: "Nos seus romances históricos, e até em Lendas e narrativas, (Herculano) não se coíbe de dizer que inventou quando os documentos não eram suficientes ou quando o quadro recriado oferecia mais potencialidades poéticas" (MARINHO, 2003, p. 289). Vejamos, a respeito, um exemplo ilustrativo e retirado do romance Eurico, o Presbítero: "E, por isso mesmo que sobre ela pesava o mistério, a imaginação vinha aí para suprir a história" (HERCULANO, 1963, p. 41).

Tal preenchimento, por parte da imaginação ou invenção herculaniana, de um vácuo deixado pela história ou por uma escassez documental, ocorre quando, ao elevar a origem medieval da nação à condição de paradigma regenerador do presente e do futuro, o nosso

${ }^{12}$ Expressão de Edmund Wilson (apud Haroldo de Campos, 1977, p. 37). 
intelectual cria um ciclo narrativo que abrange todo o processo de fundação da pátria lusitana e de afirmação do sentimento autonomista do seu povo; consulta documentos históricos, inventa, elabora uma ficção epicizante, num trabalho literariamente enciclopédico.

Por isso a preocupação de Herculano com a criação de seres ficcionais excepcionais, protagonistas de um destino nacional que os transcende, ao contrário do seu mestre Walter Scott, cujos heróis costumam ser personagens medianas ou mesmo comuns: "a intenção confessada por Scott era a evasão-distração do publico, ao passo que Herculano, declaradamente, procura fazer a apologia do medieval, com vistas à educação popular" (BEIRANTE, 1991, p. 56). Heróis como Mestre Afonso Domingues, o arquiteto cego do conto “A abóboda”, ou D. Gonçalo Mendes de Maia, o Lidador do conto homônimo, ambos de Lendas e narrativas, bem como o Cavaleiro Negro do Eurico, crescem em dimensões míticas ao sopro épico que lhes infunde o estilo majestoso do prosador. E mitopoética é Hermengarda, a Donzela Velada, ou a Dama de Branco da história do presbítero, mulher lírica, meiga, fisicamente frágil, quase incorpórea, arquétipo das figuras angelicais e, ao mesmo tempo de forma sui generis, conscienciosa, determinada, corajosa, espiritualmente forte. O próprio Herculano, na última nota de rodapé de Eurico, o presbítero, reconhece a excepcionalidade de personagens desse romance. Vejamos: "O meu herói do Crissus é como o último semideus que combate na Terra; os foragidos de Covadonga são como os primeiros cavaleiros da longa, patriótica e tenaz cruzada da Península contra os sarracenos” (HERCULANO, 1963, p. 229).

Todo o discurso de marcas digressivas e/ou dialógicas em Herculano manifesta-se com frequência entre os pré-românticos e os românticos, até a publicação daquele que é considerado o primeiro romance realista da literatura universal: Madame Bovary (1857), de Gustave Flaubert. Depois, o aludido discurso somente começa a voltar à cena a partir do último quartel do século XIX e o início dos Novecentos, quando, com a crise da representatividade na arte, é retomada a técnica interveniente da ironia romântica, conceito que, a carregar a sua herança alemã, vem a ser uma marca da modernidade de um Thomas Mann, especialmente no romance Doutor Fausto (1947).

Antes disso, o Realismo-Naturalismo promove o apagamento estratégico do autor/narrador e do narratário (virtual leitor), em nome do mito da neutralidade na representação, de uma pretensa narrativa literária isenta e impessoal, que deve basear-se na observação analítica e selecionar assuntos contemporâneos. Por isso, durante o positivista estilo de época retromencionado, o passado constitui objeto da ciência e, assim, a ficção 
histórica, agora vista como gênero menor, ou é deixada de lado ou fica em segundo plano, a exemplo do que ocorre com o arqueológico romance épico-realista Salambô (1862), outra obra-prima de Flaubert, mas sem a mesma grandiosidade de Madame Bovary.

\section{Considerações finais}

No presente artigo, verificamos que, na sua produção escrita, Alexandre Herculano demonstra uma consciência metalinguística sob a forma de discurso autoral, cujo destaque reside não na sua dimensão científica, como quer certa tradição crítica, mas sim numa dupla face lítero-histórica, representante tanto das ciências humanas, quanto da ficção verbal. Mediante essa expressão bifacial, Herculano se autorrepresenta, por trazer informações úteis e necessárias à compreensão e ao julgamento da sua concepção de mundo, dos seus valores gerais, e se revela ciente do seu processo de composição, pela autorreflexão sério-estética, a autossátira e a ironia romântica. Consequentemente, ele se encontra nas origens da prosa moderna em vernáculo.

Por via de tais recursos, observamos que o prosador lusitano concebe a história como um discurso seco, uma verdade factual, ao passo que concebe a literatura como um discurso humano, a "verdade" mais profunda de um povo, o seu gênio ou espírito, que, à luz da história, é inexprimível. Por fim, constatamos que o nosso intelectual lítero-histórico estabelece um recorrente diálogo com o leitor e chama-lhe a atenção, no caso dos seus contos, novelas e romances, para o estatuto ficcional, não obstante essas narrativas serem baseadas em fatos do passado nacional.

\section{Referências}

BEIRANTE, Cândido. Alexandre Herculano: as faces do poliedro. Lisboa: Vega, 1991. BERARDINELLI, Cleonice. Dona Branca, ou a conquista do Algarve. In. Leituras: Revista da Biblioteca Nacional. Lisboa: S.3, n. 4, abril-out., 1999.

BERNSTEIN, Harry. Alexandre Herculano: Portugal's prime historian and historical Novelist. Paris: Fundação Calouste Gulbenkian, 1983.

BOHR, Niels. Atomic physics and human knowledge. New York: Science Editions Inc., 1961. BURKE, Peter. O que é história cultural? Rio de Janeiro: Zahar, 2005. 
BORGES, Alexandre. Eurico, o presbitero, de Alexandre Herculano. In. Nove livros portugueses que deviam ser transformados em filmes. Disponível em: <https://nit.pt/coolt/1018-2016-9-livrosportugueses-que-deviam-ser-transformados-em-filmes/attachment/45464>. Acesso em: 20 de março de 2020.

CAMPOS, Haroldo de. A dimensão metalinguística. In. Ruptura dos gêneros na literatura latino-americana. São Paulo: Perspectiva, 1977.

CAPRA, Fritjof. O ponto de mutação. Trad. de Álvaro Cabral. São Paulo: Cultrix, 1996.

CIDADE, Hernani. Lições de cultura luso-brasileira. Rio de Janeiro: Livros de Portugal, 1960. DURIGAN, Jesus Antonio. Sete pontos “insigni-ficantes" relacionados com a obra de Alexandre Herculano. In. Revista Estudos Portugueses e Africanos, nº. 2, nov., 1983.

FERRAZ, Maria de Lourdes. A ironia romântica. Lisboa: INCM, 1987.

GINZBURG, Carlo et al. A micro-história e outros ensaios. Trad. António Narino. Lisboa: DIFEL, 1991.

HEGEL, Friedrich. Estética. Lisboa: Guimarães Ed., 1980.

HERCULANO, Alexandre. Eurico, o presbítero. São Paulo: DIFEL, 1963. . História da origem e estabelecimento da Inquisição em Portal. Lisboa: EuropaAmérica, s.d. Lendas e narrativas. S. Paulo: W. M. Jackson Inc, 1952. O monge de Cister. Rio de Janeiro: Tecnoprint, s.d.

LEITE, Lígia Chiappini Moraes. A tipologia de Norman Friedman. In. O foco narrativo. São Paulo: Ática, 1994.

LIMA, Alceu Amoroso. Introdução à literatura brasileira. In. TELES, Gilberto Mendonça (Org.). O pensamento estético de Alceu Amoroso Lima II. Rio de Janeiro: Educam; Paulinas, 2001.

MACHADO, Duda. Alexandre Herculano: o cavaleiro romântico e liberal. Posfácio a $O$ bobo. São Paulo: Ática, 1997.

MARINHO, Maria de Fátima. O romance histórico de Alexandre Herculano. In. Revista da Faculdade de Letras. Porto. II série. Vol. IX, 1992.

McLUHAN, Marshall; FIORE, Q. Guerra e paz na aldeia global. Rio de Janeiro: Record, 1971. MOISÉS, Massaud. A literatura portuguesa. São Paulo: Cultrix, 1981.

NEMÉSIO, Vitorino. Prefácio a Lendas e narrativas. Amadora: Bertrand, 1970. 
NIZZA DA SILVA, Maria Beatriz. Alexandre Herculano: o historiador. Rio de Janeiro: Agir, 1964.

OLIVEIRA, Paulo Fernando da Motta. Esperança e decadência: as imagens de Portugal na segunda série de “A Águia”. Tese de doutorado. Campinas: Unicamp, 1995.

RAMOS JÚNIOR, José de Paula. A ilustre casa de Ramires: roteiro de leitura. São Paulo: Ática, 1993.

RICOEUR, Paul. Temps et récit: l'intrigue et le récit historique. Paris: Éditions du Seuil, Tome I, 1991.

. Temps et récit: le temps raconté. Paris: Éditions du Seuil, Tome III, 1991.

TRINDADE, Manuel. O padre em Herculano. Lisboa: Verba, 1965.

VIGNY, Alfred de. Réflexions sur la vérité dans l'art. In. Cinq-Mars. Paris: Gallimard, 1980.

WHITE, Hayden. Meta-história: a imaginação histórica do século XIX. Trad. José Laurênio de Melo. São Paulo: Edusp, 1995. 